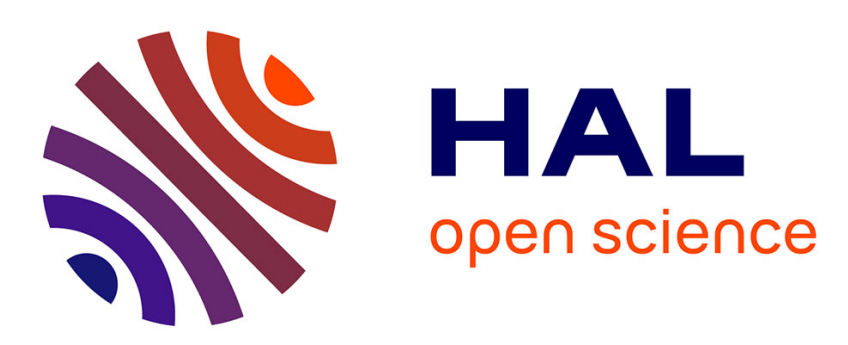

\title{
In vivo evaluation of antiparasitic activity of plant extracts on Nosema ceranae (Microsporidia)
}

Martín Porrini, Natalia Fernández, Paula Garrido, Liesel Gende, Sandra Medici, Martín Eguaras

\section{- To cite this version:}

Martín Porrini, Natalia Fernández, Paula Garrido, Liesel Gende, Sandra Medici, et al.. In vivo evaluation of antiparasitic activity of plant extracts on Nosema ceranae (Microsporidia). Apidologie, 2011, 42 (6), pp.700-707. 10.1007/s13592-011-0076-y . hal-01003613

\section{HAL Id: hal-01003613 \\ https://hal.science/hal-01003613}

Submitted on 1 Jan 2011

HAL is a multi-disciplinary open access archive for the deposit and dissemination of scientific research documents, whether they are published or not. The documents may come from teaching and research institutions in France or abroad, or from public or private research centers.
L'archive ouverte pluridisciplinaire HAL, est destinée au dépôt et à la diffusion de documents scientifiques de niveau recherche, publiés ou non, émanant des établissements d'enseignement et de recherche français ou étrangers, des laboratoires publics ou privés. 


\title{
In vivo evaluation of antiparasitic activity of plant extracts on Nosema ceranae (Microsporidia)
}

\author{
Martín Pablo Porrini ${ }^{1,2}$, Natalia Jorgelina Fernández ${ }^{1,3}$, Paula Melisa Garrido ${ }^{1,3}$, \\ Liesel Brenda Gende ${ }^{1,3}$, Sandra Karina MedicI ${ }^{1,3}$ \\ Martín Javier EgUARAs 1,3 \\ ${ }^{1}$ Arthropods Laboratory, School of Exact and Natural Sciences, National University of Mar del Plata, Funes 3350 \\ (7600) Mar del Plata, Argentina \\ ${ }^{2}$ Agencia Nacional de Promoción Científica y Técnológica, Buenos Aires, Argentina \\ ${ }^{3}$ Consejo Nacional de Investigaciónes Científicas y Técnicas, Buenos Aires, Argentina
}

Received 2 November 2010 - Revised 31 January 2011 - Accepted 17 February 2011

\begin{abstract}
This study evaluated the activity of plant extracts on Nosema ceranae development and their toxicity on the infected host Apis mellifera. Newly emerged bees were fed ad libitum with enriched syrups after individual infection. Diets consisted of ethanolic extracts obtained from Artemisia absinthium, Allium sativum, Laurus nobilis, and Ilex paraguariensis diluted in syrup at $1 \%$ and $10 \%$ concentrations. Examination of individual midgut homogenates on day 19 post-infection indicated that $1 \%$ concentration of $L$. nobilis extract significantly inhibited $N$. ceranae development. Absinth extract, previously reported as effective against Nosema apis, did not diminish the number of $N$. ceranae spores throughout the experiment. Ten percent concentrations showed high toxicity on infected bees, but also a significant activity diminishing parasitosis development in short periods. Syrups with the addition of extracts were consumed avidly as the control, even more in some cases. The present study constitutes the first report of antiparasitic activity in vivo of plant extracts against the Microsporidian $N$. ceranae and postulate natural substances as an alternative for antiparasitic treatment.
\end{abstract}

Apis mellifera / Nosema ceranae / plant extract / antiparasitic treatment

\section{INTRODUCTION}

Among parasites affecting honeybees, nosemosis caused by Nosema ceranae is one of the most prevalent and pathogenic (MartínHernández et al. 2007; Higes et al. 2007; Paxton et al. 2007). This intracellular parasite has recently shifted hosts and seems to be the main microsporidian infection in Apis mellifera colonies (review in Fries 2010). These highly specialized fungi (Keeling and Fast

Corresponding author: M.P. Porrini, mporrini@mdp.edu.ar

Manuscript editor: David Tarpy
2002) are obligate intracellular parasites that spread among cells and hosts via spores.

The effective control of this disease is carried out by administering the antibiotic fumagillin (dicyclohexylammonium), which temporarily reduces parasitosis (Williams et al. 2008). This drug is the only one available for treatment and is no longer allowed in most EU member states because of possible residues in honey.

Research efforts to find effective and noncontaminant compounds against $N$. ceranae infection have been undertaken using different substances, such as essential oils, lisozime, thymol, and fitolexin resveratrol (Maistrello et al. 2008; Costa et al. 2010), as well as bacterial metabolites (Porrini et al. 2010). 
Higher plants have been traditionally used as extracts to treat a number of infectious diseases, including those caused by bacteria, fungi, protozoa, and viruses (Soylu et al. 2005; Yoshida et al. 2005; Nejad and Deokule 2009). However, these substances are largely unexploited in conventional animal production and their effect on honeybees has been little studied (Pohorecka 2004a). The biological activity of extracts have been demonstrated against bee pathologies, such as American Foulbrood (the disease caused by the sporulated bacteria Paenibacillus larvae; Gende et al. 2008) and the parasitic mite Varroa destructor (Damiani 2010). Also, Artemisia absinthium extract has been tested against Nosema apis (Pohorecka 2004b), the first reported etiological agent of nosemosis in $A$. mellifera.

The aim of this work was to evaluate the bioactivity of plant extracts on $N$. ceranae development under laboratory conditions, with the particular goal of developing formulations for disease treatment, based on widely available plants.

\section{MATERIALS AND METHODS}

\subsection{Bee collection and assays conditions}

Experiments were carried out from November to December 2009 in the Arthropods Laboratory at the Universidad Nacional de Mar del Plata (Argentina). Newly emerged A. mellifera bees were obtained from a colony located in the experimental apiary J. J. Nágera coastal station, placed on route $11 \mathrm{~km} 32\left(38^{\circ}\right.$ $\left.10^{\prime} 06^{\prime \prime} \mathrm{S}, 57^{\circ} 38^{\prime} 10^{\prime \prime} \mathrm{W}\right)$ and kept under incubator conditions during the experiment $\left(32^{\circ} \mathrm{C} \pm 0.79 ; 60 \% \pm\right.$ $3.3 \mathrm{HR})$.

\section{$2.2 N$. ceranae strains}

The Nosema spores used for inoculation were purified from a laboratory strain developed in confined workers. Spores were molecularly characterized following Martín-Hernández et al. (2007). Sequencing results were entered in the GenBank BLASTn, which yielded $98 \%$ homology with $N$. ceranae (accession number FJ425736).

\subsection{Preparation of crude ethanolic extracts}

Plant material was obtained as follows. Dry leaves of laurel, Laurus nobilis L. (Lauraceae), and absinth, Artemisia absinthium L. (Asteraceae); dry leaves and stems/trunks of yerba mate, Ilex paraguariensis St.Hil. (Aquifoliaceae); and garlic cloves, Allium sativum L (Liliaceae) were collected in different geographic area from Argentina: laurel was obtained from Henderson ( $\left.36^{\circ} 18^{\prime} \mathrm{S} ; 61^{\circ} 42^{\prime} \mathrm{W}\right)$, Buenos Aires Province; absinth from Chapadmalal $\left(38^{\circ} 10^{\prime} 06^{\prime \prime} \mathrm{S}\right.$; $57^{\circ} 38^{\prime} 10^{\prime \prime}$ W) Buenos Aires Province; yerba mate and garlic were obtained as commercial samples packed in Misiones Province and Buenos Aires Province respectively. The samples of laurel and absinth were identified and deposited in the Faculty of Exact and Natural Sciences, National University of Mar del Plata herbarium.

After drying at $37^{\circ} \mathrm{C}$ for $24 \mathrm{~h}$, the plant material was ground using mortar and pestle. Exposure to sunlight was avoided to prevent the loss of active components.

\subsection{Extraction of selected plant material powder by maceration method}

Five hundred milliliters of an $80 \%$ ethanol (extraction fluid) was mixed with $100 \mathrm{~g}$ of plant material. The mixtures were kept for 5 days in tightly sealed vessels at room temperature at $20^{\circ} \mathrm{C}$, protected from sunlight, and mixed several times daily. This mixture was vacuum filtered and further extraction of the residue was repeated once until a clear colorless supernatant extraction liquid was obtained. The extracted liquid was subjected to evaporation in a water bath $\left(40^{\circ} \mathrm{C}\right)$ to remove the ethanol until a semisolid state of extracted liquid was obtained. The semisolid extract produced was stored at $4{ }^{\circ} \mathrm{C}$ until use ( 2 months for L. nobilis, $Y$. paraguayensis, and A. sativum while A. absinthium was used immediately after extraction).

\subsection{Experimental design}

The toxicity of the extracts on A. mellifera infected with $N$. ceranae and their antiparasitic effect was evaluated systematically. Ninety individuals per treatment ( 3 replicates of 30 bees), confined to experimental wooden cages with a plastic mesh $\left(11 \times 9 \times 6 \mathrm{~cm}^{3}\right)$ participated in this assay. Workers were carefully removed from brood combs from the same colony 
within $6 \mathrm{~h}$, randomly confined, and supplied with sugar syrup $60 \%(w / v)$. Individual infection was achieved on day 3 (after emergence) using a technique modified from that published by Rinderer (1976). By means of this technique, bees are not anesthetized. Consumption of the inoculum occurs in a small container and is induced by previous starvation, thereby preventing oral structures manipulation to force intake and so minimizing the stress resulting from prolonged handling.

Bees were individually infected with $10 \mu \mathrm{L}$ of solution $\left(2.03 \times 10^{4}\right.$ spores $)$ and then supplied with one of the following diets: syrup enriched with $1 \%$ or $10 \%$ plant extract (garlic, laurel, absinth, or yerba mate) or control syrup. After inoculation, extracts dilutions were administered ad libitum, replacing the volumes on a daily basis until the end of the experiment. Extracts were supplied in cane sugar syrup so as to force bees to incorporate them in each feeding. In order to control unwanted infection due to food contamination, manipulation, or incidental ingestion of spores when the operculum is cut during bee emergence, 30 bees were confined to one cage. They were individually inoculated with $60 \%(w / v)$ sucrose syrup without spores (keeping the same diet after inoculation) and sacrificed at the end of the assay to quantify presence of spores on their midgut.

On days 7, 15, and 19 post-infection (p.i.), five bees per replicate were sacrificed in order to individually quantify the number of spores in the midgut (Cantwell 1970). Solutions evaporation was controlled to correct the consumed volumes.

\subsection{Statistic analysis}

Duncan multiple comparison test $(\alpha=0.05)$ was performed to test differences in spore loads. This test was used to determine significant differences among group means in the analysis of variance.

For each treatment, survival curves plotting number of live bees versus time were constructed using data from each cage. Gehan-Breslow nonparametric test was performed to determine whether survival curves were significantly different. Pairwise multiple comparisons were performed with Holm-Sidak method.

To verify the bees' dietary preference towards the experiment, average daily feed intake was compared using Kruskal-Wallis nonparametric test and com- parisons with control treatment were performed by means of Dunn's method.

The statistical analysis of the results obtained was conducted applying $\alpha=0.05$.

\section{RESULTS}

Significant differences in the number of Nosema spores occurred 7 days after artificial inoculation. At this time, $10 \%$ treatments of laurel $\left(6,6 \times 10^{4}\right.$ spores on average) and yerba mate $\left(5,5 \times 10^{4}\right.$ spores on average) showed spore counts significantly lower than control $\left(2,2 \times 10^{6}\right.$ spores on average; $p=0.037$ and $p=$ 0.017 , respectively).

On day 15 p.i. (Figure 1), garlic 1\% treatment reached higher spore loads than those registered by yerba mate and laurel $1 \%(P=0.007$ and $P=0.003$, respectively) but showed no differences with control treatment $(P=0.084)$. Bees receiving $1 \%$ concentration treatments, except yerba mate, survived until the end of the experiment. Examination of individual midgut homogenates indicated that $1 \%$ concentration of L. nobilis extract significantly inhibited $N$. ceranae development on day 19 , being the only treatment different from control at this time $(P=$ 0.017).

Bees not inoculated with spores did not develop a detectable level of disease at the end of the experiment. Survival data of these bees is not presented due to lack of replicates. Survival curves of bees fed with garlic, laurel, and absinth at $1 \%$ concentration did not differ significantly from control curve. Ten percent extract concentrations showed significantly lower median survival time compared to $1 \%$ groups for each herb (Figure 2, Table I).

At the end of the experiment, KruskalWallis test $(H=20.283$, d.f. $=8, P=0.009)$ and Dunn's multiple comparison procedure showed garlic $1 \%$ and laurel $1 \%$ as groups with higher daily intake than control treatment $(P<0.05)$. The following average values of daily intake (microliter) were registered for every treatment at $1 \%$ and $10 \%$ concentration respectively: absinth 22.57 and 27.97; laurel 27.61 and 


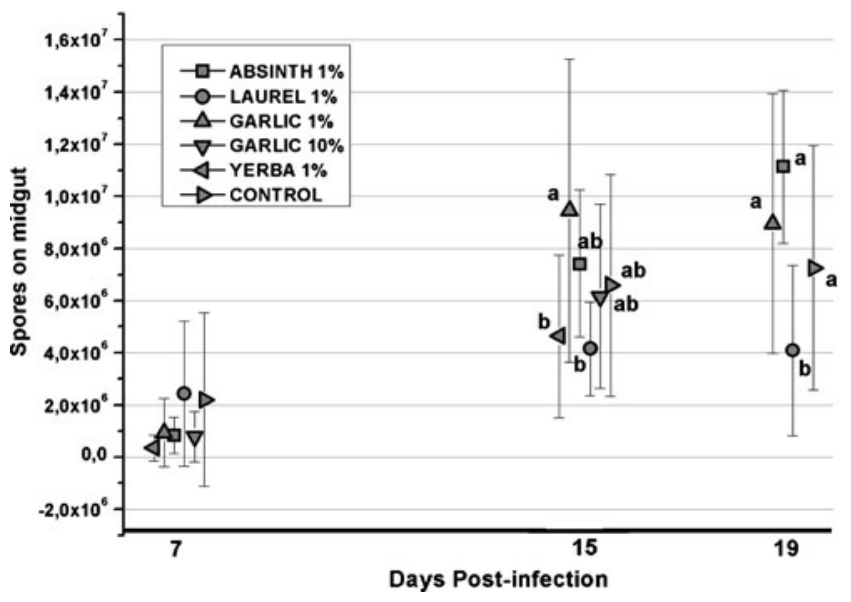

Figure 1. Parasitosis development for treatments alive after day 7 p.i. (absinth $1 \%$, laurel $1 \%$, garlic $1 \%$, and $10 \%$, yerba maté $1 \%$, control treatment). Different letters indicate significant differences between treatments on the same day (Duncan test - approximate probabilities for post hoc tests, $P<0.05$ ). On day 7 , no significant differences were detected between treatments.

22.95; garlic, 29.09 and 23.07; yerba mate, 23.30 and 21.18; control, 21.60 .

It is worth noting that treated individuals showed no excessive droppings during confinement.

\section{DISCUSSION}

Our results demonstrate that $L$. nobilis extract is effective inhibiting in vivo development of $N$. ceranae. The time of action of this extract depended on its dosage. While $1 \%$ concentration significantly inhibited $N$. ceranae development after 19 days of treatment, $10 \%$ concentration seemed to be effective in a shorter period of time, decreasing parasitosis intensity but causing high mortality on bees. The antimicrobial activity of this herb was previously reported against another fungus species, such as Candida albi-

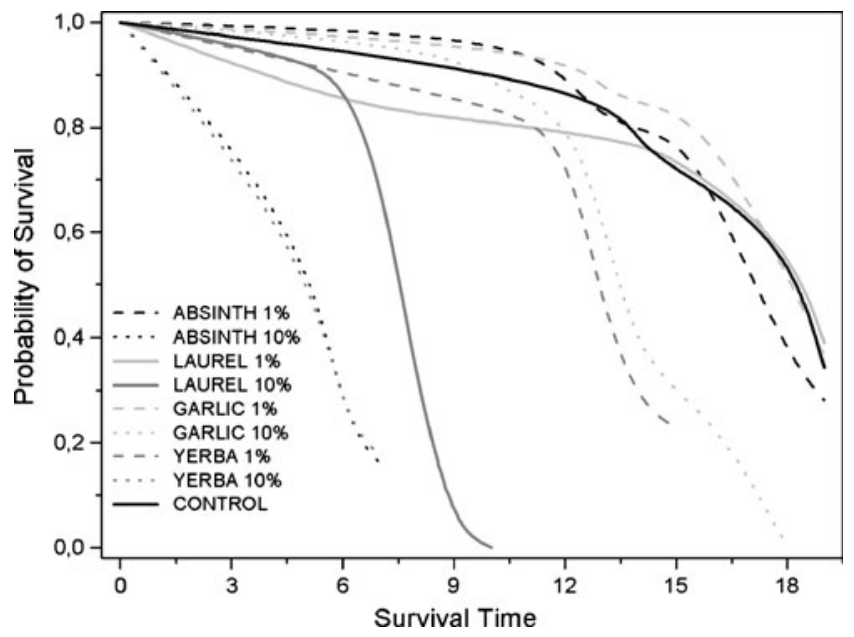

Figure 2. Survival curves from Gehan-Breslow test. 


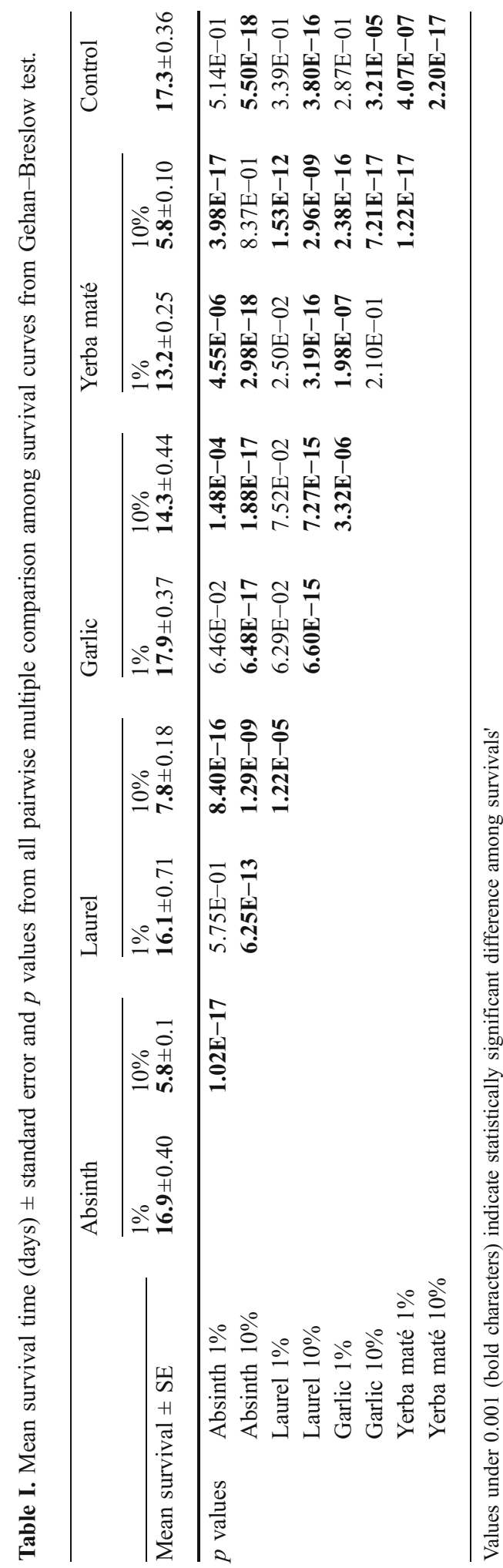

cans and Aspergillus niger, showing higher inhibitory activity than the standard antifungal nystatin (Ertürk 2006). To the best of our knowledge, this study is the first report of antimicrosporidian activity of $L$. nobilis extract and, therefore, the ways of action remain unclear and further research is necessary to determine the identity of the active compounds. In any event, multiple constituents of plant extracts may be responsible of the therapeutic activity, being also possible synergic, additive, and antagonistic effects among the different compounds. Because of this, in future designs, the complete extract could be considered like an active "compound" (He 2000; Ong 2004).

A. absinthium extract, until now, the only herb extract tested against Nosema genus, was reported by Pohorecka (2004b) as inhibitor of $N$. apis after 17 days of treatment. However, our study found that both the highest concentration of absinth extract (10\%) such as prolonged consumption of $1 \%$ concentration did not diminish the spore load of parasitic infection throughout the experiment. The differences between the two studies could be explained by a lower susceptibility of $N$. ceranae to the ethanolic extract of this herb or by factors that can influence on the chemical composition of the obtained substances, such as the extraction method (Tariq et al. 2009; Ahameethunisa and Hopper 2010). Pohorecka (op cit) administered a dilution of "standardized extract" without extraction method specifications, thus differences with these experiments may be attributable to this variable.

Despite the broad antiprotozoal activity of garlic (Mirelman et al. 1987; Ankri et al. 1997; Ankri and Mirelman 1999), ethanolic extracts from this plant tested at two concentrations did not influence significantly $N$. ceranae development along the experiment, even though $1 \%$ extract was consumed more than control syrup. The efficacy of chemical constituents of garlic chiefly depends on the mode of preparation and conservation of its extract. Allicin is one of the main active compounds of fresh garlic, but it is also one of the least stable (Block 1992; Lawson and Block 1997) with a half-life time which decreases significantly after contact with 
ethanol (Lawson 1993). Therefore, future experiments involving the administration of non-ethanolic extracts and less storage time could provide different results.

The control of nosemosis disease in honeybee colonies requires treatments with an acceptable anti-microsporidial activity, without side effect on honeybees and minimizing toxic residues in wax and honey. Adamczyk et al. (2005) concluded that the presence of residues of natural substances in honey samples does not represent a sanitary risk, only that it may change the taste of the honey. As for bees, extracts tested in our experiment did not affect adversely the consumption of syrup. Furthermore, in some cases it was increased in comparison to control diet (i.e., garlic 1\%, laurel 1\%).

In our study, the spore load remaining after $L$. nobilis treatment (about four million) was significantly lower than other treatments and control, but mortality did not differ between them. These results are supported by previous studies (Mayack and Naug 2009; Porrini et al. 2011), which demonstrated that workers infected with $N$. ceranae survived just as well as uninfected or less-infected bees when fed ad libitum.

There is little information about the effect of plant extracts on honeybee health. Pohorecka (2004a), administering various standardized extracts, found no effect on midgut $\mathrm{pH}$, no significant differences in pharyngeal glands degeneration during the experiment, and an increased fat body development (only for nettle extract). In the present study, extracts of garlic, absinth, and laurel at $1 \%$ concentration showed a median survival similar to control and, therefore, its toxic effect on young bees would be minimal. Given this low mortality, $1 \%$ concentration is recommended for long-term experiments.

Many vegetable extracts include some secondary products, such as polyphenols, which are toxic to insects (review in Berbehenn and Martin 1994). Honeybees usually avoid the contact with nectars that contains such secondary compounds (Adler 2000), but in our study, diet selection was not allowed. The high toxicity of yerba mate, inclusively at $1 \%$ concentration, may be explained by the presence of these (Rodríguez Vaquero et al.
2009) or similar substances. Some polyphenols, such as resveratrol, have shown significant activity against microsporidia (Leiro et al. 2004) and specifically against $N$. ceranae (Maistrello et al. 2008). As such, the decreasing effect on $N$. ceranae development obtained for higher concentrations of laurel and yerba mate extracts on day 7 p.i. should be studied in future experiments.

It should be noted that the substances administered may have different effects if they are fed to bee colonies. Therefore, it is necessary to test the studied substances under natural conditions, where the protein flow, survival of brood, and interaction with pollen and ventricular microbiota are variables to consider. Also, association of antibiotics and natural compounds showed synergistic activity on honeybee pathogenic bacteria (Gende 2009), therefore interactions with drugs such as oxitetracycline and fumagillin, commonly administered in field colonies, would also be interesting to study.

The significant antiparasitic activity of laurel, coupled with its palatability and low toxicity noticed during the assay, makes its inclusion feasible in a compound for nosemosis control. Ethanol extracts often have low antimicrobial action in relation to essential oils (Nanasombat and Lohasupthawee 2005; Gende et al. 2008). For this reason, it will be interesting to test compounds isolated from this herb.

\section{ACKNOWLEDGMENTS}

The authors wish to thank CONICET, UNMdP. This research was supported by ANPCyT (FONCyT), project PICT 890/06, to M.E. We thank the support provided by the 426 Animal Production Department, EEA INTA, Balcarce, the Fares Taie Laboratories Food Division and the contribution made by Enrique Tkacik.

Evaluation in vivo de l'activité anti-parasitaire d'extraits de plantes sur Nosema ceranae (Microsporidia)

Apis mellifera / Nosema ceranae / extrait de plante / traitement anti-parasitaire

Eine in vivo Methode zur Beurteilung der antiparasitischen Wirkung von Pflanzenextrakten gegen Nosema ceranae (Microsporidia) 


\section{Apis mellifera / Nosema ceranae / Pflanzenextrakt / antiparasitische Behandlung}

\section{REFERENCES}

Adamczyk, S., Lázaro, R., Pérez-Arquillué, C., Conchello, P., Herrera, A. (2005) Evaluation of residues of essential oil components in honey after different antiVarroa treatments. J Agric Food Chem. 53,1008510090. doi:10.1021/jf051813f

Adler, L.S. (2000) The ecological significance of toxic nectar. Oikos 91, 409-420

Ahameethunisa, A.R., Hopper, W. (2010) Antibacterial activity of Artemisia nilagirica leaf extracts against clinical and phytopathogenic bacteria. BMC Comp Altern Med 10, 6. http://www.biomedcentral.com/ $1472-6882 / 10 / 6$

Ankri, S., Mirelman, D. (1999) Antimicrobial properties of allicin from garlic. Microbes Infect 2(2), 125-9 doi:10.1016/S1286-4579(99)80003-3

Ankri, S., Miron, T., Rabinkov, A., Wilchek, M., Mirelman, D. (1997) Allicin from garlic strongly inhibits cysteine proteinases and cytopathic effects of Entamoeba histolytica. Antimicrob. Agents Chemother. 10, 2286-2288

Berbehenn, R.V., Martin, M.M. (1994) Tannin sensitivity in larvae of Malacosoma disstria (Lepidoptera): roles of the pertitrophic envelope and midgut oxidation. J. Chem. Ecol. 20, 1985-2001

Block, E. (1992) The organosulfur chemistry of the genus Allium -Implication for the organic chemistry of sulfur. Angew. Chem. Int. 31, 1135-1178

Cantwell, G.E. (1970) Standard methods for counting nosema spores. Am. Bee Jj. 110, 220-223

Costa, C., Lodesani, M., Maistrello, L. (2010) Effect of thymol and resveratrol administered with candy or syrup on the development of Nosema ceranae and on the longevity of honeybees (Apis mellifera L.) in laboratory conditions. Apidologie 41, 141-150

Damiani, N. (2010) Control del parásito Varroa destructor (Acari: Varroidae) en colmenas de Apis mellifera (Hymenoptera: Apidae). Doctoral thesis. School of Exact and Naturals Science. National University of Mar del Plata. Argentina (in Spanish)

Ertürk, O. (2006) Antibacterial and antifungal activity of ethanolic extracts from eleven spice plants. Sect. Cell. Mol. Biol. 61, 275-278

Fries, I. (2010) Nosema ceranae in European honey bees (Apis mellifera). J Invertebr. Pathol. 103, 73-79

Gende, L.B. (2009) Principales componentes de aceites esenciales relacionados con actividad antimicrobiana frente a Paenibacillus larvae. Doctoral thesis. School of Pharmacy and Biochemistry. University of Buenos Aires. Argentina (in Spanish).

Gende, L.B., Principal, J., Maggi, M.D., Palacios, S.M., Fritz, R., Eguaras, M.J. (2008) Extracto de Melia azedarach y aceites esenciales de Cinnamomun zeylanicum, Mentha piperita y Lavandula officinalis como control de Paenibacillus larvae. Zoot. Trop. 26, $151-156$

He, X.G. (2000) On-line identification of phytochemical constituents in botanical extracts by combined highperformance liquid chromatographic-diode array detection-mass spectrometric techniques. J. Chromatogr. 880, 203-232

Higes, M., García-palencia, P., Martín-Hernández, R., Meana, A. (2007) Experimental infection of Apis mellifera with Nosema ceranae (Microsporidia). J. Invertebr. Pathol. 94, 211-217

Keeling, P.J., Fast, N.M. (2002) Microsporidia: Biology and evolution of highly reduced intracellular parasites. Annu. Rev. Microbiol. 56, 93-116

Lawson, L.D. (1993) Bioactive organosulfur compound of garlic and garlic products: role in reducing blood lipids. In: Kinghorn, A.D., Balandrin, M.F. (eds.) Human medicinal agents from plants, pp. 306-330. American Chemical Society, Washington

Lawson, L.D., Block, E. (1997) Comments on garlic chemistry stability of s-(2-propenyl) 2 propene-1sulfinothioate (allicin) in blood solvents and stimulated physiological fluids. J. Agric. Food. Chem. 45, 542

Leiro, J., Cano, E., Ubeira, F.M., Orallo, F., Sanmartìn, M.L. (2004) In vitro effects of resveratrol on the viability and infectivity of the Microsporidian Encephalitozoon cuniculi. Antimicrob. Agents Ch. 48, 2497-2501

Maistrello, L., Lodesani, M., Costa, C., Leonardi, F., Marani, G., Caldon, M., Mutinelli, F., Granato, A. (2008) Screening of natural compounds for the control of nosema disease in honey bees (Apis mellifera). Apidologie 39, 436-444

Martín-Hernández, R., Meana, A., Prieto, L., Martínez, S.A., Garrido-Bailón, E., Higes, M. (2007) Outcome of Colonization of Apis mellifera by Nosema ceranae. Appl. Environ. Microbiol. 73, 6331-6338

Mayack, C., Naug, D. (2009) Energetic stress in the honey bee Apis mellifera from Nosema ceranae infection. J. Invertebr. Pathol. 100(3), 185-188

Mirelman, D., Monheit, D., Varon, S. (1987) Inhibition of growth of Entamoeba histolytica by Allicin, the active principle of garlic extract (Allium sativum). J. Infect. Dis. 156, 243-244

Nanasombat, S., Lohasupthawee, P. (2005) Antibacterial activity of crude ethanolic extracts and essential oils of spices against salmonellae and other enterobacteria. Sci. Tech. J. 5, 462-469

Nejad, B.S., Deokule, S.S. (2009) Anti-dermatophytic activity of Drynaria quercifolia (L.). Jundishapur. J. Microbiol. 2, 25-30

Ong, E.S. (2004) Extraction methods and chemical standardization of botanicals and herbal preparations. J. Chromatogr. 812, 23-33

Paxton, R.J., Klee, J., Korpelab, S., Fries, I. (2007) Nosema ceranae has infected Apis mellifera in 
Europe since at least 1998 and may be more virulent than Nosema apis. Apidologie 38, 558-565

Pohorecka, K. (2004a) Effect of standardized plant herb extracts on general condition of the honeybee (Apis mellifera 1.). Bull. Vet. Inst. Pulawy. 48, 415-419

Pohorecka, K. (2004b) Laboratory studies on the effect of standardized Artemisia absinthium L. extract on Nosema apis infection in the worker Apis mellifera. J. Apic. Sci. 48, 131-136

Porrini, M.P., Audisio, M.C., Sabaté, D.C., Ibarguren, C., Medici, S.K., Sarlo, E.G., Garrido, P.M., Eguaras, M.J. (2010) Effect of bacterial metabolites on microsporidian Nosema ceranae and on its host Apis mellifera. Parasitol. Res. 107, 381-388

Porrini, M.P., Sarlo, E.G., Medici, S.K., Garrido, P.M., Porrini, D.P., Eguaras, M.J. (2011) Nosema ceranae development in Apis mellifera: Influence of diet and infective inoculum. J. Apic. Res. 50(1), 35-41

Rinderer, T.E. (1976) Honey bees: individual feeding of large numbers of adult workers. J. Econ. Entomol. 69, 489-491

Rodríguez Vaquero, M.J., Tomassini Serravalle, L.R., Manca de Nadra, M.C., Strasser de Saad, A.M.
(2009) Antioxidant capacity and antibacterial activity of phenolic compounds from argentinean herbs infusions. Food Control. 21, 799-785

Soylu, E.M., Tok, F.M., Soylu, S., Kaya, A.D., Evrendilek, G.A. (2005) Antifungal activities of essential oils on post harvest disease agent Penicillium digitatum. Pak. J. Biol. Sci. 8, 25-29

Tariq, K.A., Chishti, M.Z., Ahmada, F., Shawl, A.S. (2009) Anthelmintic activity of extracts of Artemisia absinthium against ovine nematodes. Vet. Parasitol. 160, 83-88

Williams, G.R., Sampson, M.A., Shutler, D., Rogers, R. (2008) Does fumagillin control the recently detected invasive parasite Nosema ceranae in western honey bees (Apis mellifera)? J. Invertebr. Pathol. 99, 342344

Yoshida, M., Fuchigami, M., Nagao, T., Okabe, H., Matsunaga, K., Takata, J., Karube, Y., Tsuchihashi, R., Kinjo, J., Mihashi, K., Fujioka, T. (2005) Antiproliferative constituents from Umbelliferae plants VII. Active triterpenes and rosmarinic acid from Centella asiatica. Biol. Pharmacol. Bull. 28, 173-175 